\title{
MANAJEMEN PELAYANAN SOSIAL DI LEMBAGA PANTI ASUHAN HASANA PEKANBARU
}

\author{
Kodarni \\ Dosen Jurusan Ilmu Komunikasi, Fakultas Dakwah dan Komunikasi,UIN Suska Riau, \\ Jl. HR Soebrantas Km 15 Simpangbaru, Tampan, Pekanbaru 50275
}

\begin{abstract}
Abstrak
Penelitian ini bertujuan untuk berusaha memahami arti peristiwa dan kaitankaitannya dalam situasi tertentu dari perilaku seseorang atau penyelenggara manajemen pelayanan sosial di lembaga Panti Asuhan hasana, serta melakukan kegiatan manajemen tersebut dengan menggunakan metode penelitian kualitatif Fenomenologi.Panti Asuhan Hasana merupakan salah satu panti asuhan hasana secara manajemen sangat baik, tertata dan terkelola sehingga menjadi panti asuhan hasana yang dapat dicontoh di kota pekanbaru. hasil penelitian sebagai berikut:pertama, Perencanaan dilakukan sebelum pelaksanaan kegiatan pelayanan sosial kepada anak di panti, sedangkan seluruh civitas akademika. Keterlibatan seluruh unsur dalam perencanaan menjadi hal yang sangat penting baik yang dibuat diawal tahun ajaran baru, pemberian bimbingan dan arahan kepada anak asuh, pertengahan semester, mingguan bahkan harian. Selalu diawasi baik oleh pengurus panti maupun oleh guru yang mengajar. Kedua, Pengorganisasian yang dilakukan antar unit yang ada atau antar lintas kelas sesuai dengan prosedur pelayanan sosial, mulai dari identifikasi sampai pada intervensi dan tindak lanjut. .Ketiga, Pelaksanaan yang dilakukan dalam berbagai aktivitas rutin di lembaga baik di kelas proses pembelajaran, di luar lembaga pada event tertentu, penggunaan metode sampai keadministrasian berjalan dengan baik. Sesuai prosedur pelayanan sosial yang dilakukan. Keempat, Pengawasan dilembaga Panti Hasanah dalam hal evaluasi berbagai kegiatan sesuai dengan pelaksanaan yang dilakukan dan rencana yang telah dilakukan seperti persiapan dan pelaksanaan proses pembelajaran di kelas maupun antar lembaga melibatkan seluruh civitas akademika yayasan, baik yayasan, kepala sekolah, guru orang tua wali murid bahkan keterlibatan anggota masyarakat.
\end{abstract}

Kata kunci: manajemen, pelayanan sosial 


\section{A. PENDAhuluan}

Keberadaan panti asuhan hasana di lingkungan Departemen khususnya di Dinas sosial di provinsi maupun Kota/kabupaten memang sudah sejak lama dengan melalui kegiatan pendidikan untuk Anak dan pelayanan sosialo bagi penerima manfaat sosial. Meski keberadaan panti dipekanbaru dalam perkembangan seakan menjadi popularitas dan hanya sekedar seremonial.

Meski demikian, potensi panti asuhan hasana sebetulnya sangat besar mengingat minat masyarakat untuk menyekolahkan anak di sekolah sejak usia dini. sementara dikalangan depertemen sosial keberadaan panti asuhan marak bermunculan dan mendapatkan minat dari masyarakat, hal ini harusnya menjadi semacam pukulan berat bagi bagi dinas pendidikan khususnya kota pekanbaru apabila tidak dikelolah dengan baik dan kesempatan berkembang secara pesat baik kualitas dan kuantitas terabaikan.

berdasarkan hasil observasi dan wawancara awal pra-penelitian diperoleh data secara kuantitas jumlah panti asuhan di kota Pekanbaru cukup banyak Panti Hasanahyang memiliki beberapa keunggulan dalam proses penyelenggaraan manajemen pelayanan sosial, panti asuhan hasana, salah satunya adalah menjadi pusat contoh bagi panti asuhan lainnya kota pekanbaru, memiliki jumlah peserta didik yang semakin bertambah, kerjasama yayasan, kepala sekolah, guru, komite dan lembaga lain cukup baik, serta prestasi dibeberapa lomba yang diadakan baik untuk anak maupun guru dan pengelolah dan terintegrasi dengan lembaga pendidikan seperti sekolah dari TK sampai SMA/SMK dalam satu kompleks. KeberadaaPanti Hasanah penyelenggaraannya dimasyarakat dipengaruhi oleh berbagai faktor baik pengelolah, peserta penyelenggara maupun pengguna. Salah Satu diantara faktor tersebut adalah penyelenggara panti asuhan hasana. ketika penyelenggara mampu menyelenggarakan panti asuhan hasana secara baik dan profesional maka alangkah sulitnya untuk dikembangkan secara profesional pula apabila tidak tahu manajemen yang dilakukan.

Kondisi tersebut di atas sangat relevan dengan ketetentuan sesuai kompetensi yang diharapkan. Dalam Peraturan Pemerintah Nomor 19 tahun 2005 tentang Standar Nasional Pendidikan (SNP) dijabarkan bahwa tenaga kependidikan dituntut memiliki kompetensi yang mencakup kompetensi pedagogis, kepribadian, sosial dan profesional. Kompetensi tersebut diharapkan dimiliki oleh seluruh tenaga pengelola lembaga pendidikan luar sekolah termasuk pengelola program Anak di Panti. Pengelola yang memenuhi kompetensi tersebut telah dimiliki oleh panti asuhan hasana it panti hasanahdan memenuhi legalitas kualifikasi sebagai tenaga pengelola program panti asuhan hasana yang profesional

Dengan demikian sebagian besar dari tenaga pengelola PANTI ASUHAN HASANA yang ada telah mendapatkan pelatihan dan pendidikan yang mendukung tugas profesinya. Sementara dari hasil pengamatan sementara yang penulis lihat dilapangan bahwa pengelolahan Panti Hasanah telah memenuhi standar baik kompetensi maupun kualitas pelayanan sosial, Kenyataan lain di lapangan bahwa pengelola panti asuhan hasana memiliki latar belakang pendidikan sarjana, pengalaman kerja sebagai orang berjiwa sosial.

Dilandasi pertimbangan di atas, melalui Penelitian yang dilakukan manajemen pelayanan sosial Anak di Panti (study kasus PANTI ASUHAN HASANA kota Pekanbaru

\section{METODE}


Penelitian ini menggunakan metode kualitatif yang mengacu kepada paradigma naturalistik yaitu paradigma alamiah yang bersumber pada pandangan fenomenologis khususnya yang berkaitan dengan teori yang dikembangkan oleh Spradley. Pandangan ini bersandar pada gejala-gejala yang menampakan diri, dimana peneliti berusaha memahami arti peristiwa dan kaitankaitannya dalam situasi tertentu dari perilaku seseorang atau penyelenggara program di lembaga PANTI ASUHAN HASANA, serta melakukan kegiatan manajemen pelayanan sosial.

Dalam penelitian kualitatif ini peneliti rencananya ikut terlibat langsung di lapangan, melihat, mendengarkan, dan ikut berpartisipasi dalam berbagai kegiatan untuk mendapatkan kebenaran empiris secara langsung berkenaan dengan penyelenggaraan manajemen pelayanan sosial di lembaga PANTI ASUHAN HASANA. Hal ini sejalan dengan pendapat Muhajir (2000:19) bahwa salah satu ciri penelitian fhenomenologik menuntut bersatunya subyek peneliti dengan subyek pendukung obyek peneliti. Dari cara penelitian tersebut menurut Moleong (2000:3), akan menghasilkan data deskriptif berupa kata-kata tertulis atau lisan dari orang-orang atau perilaku yang dapat diamati. Melalui data empiris yang terkumpul diyakini akan dapat memberi jawaban permasalahan dalam penelitian ini.

Pemilihan metode kualitatif juga didasarkan atas pertimbangan bahwa dengan menggunakan penelitian kualitatif akan dapat memberikan jawaban secara rinci, seperti mengetahui dan menemukan hal baru dalam kualitas manajemen di Panti Hasanah Pekanbaru. Hal ini sesuai dengan pendapat Straus dan Corbin(1990:3) : Qualitative methods can be used to uncover and understand what lies behind any phenomenon about which little is yet known, and can give the intricate details of phenomena that are difficult to convey with quantitative methods. Metode kualitatif dapat digunakan untuk mengungkapkan dan memahami apa yang menjadi latar belakang sebuah fenomena, dan dapatpula memberikan data secara terinci dari sebuah fenomena yang mungkin sulit diteliti dengan metode-metode kuantitatif.

Penelitian ini tidak hanya mencari satu jawaban yang pasti dari bagaimana penyelenggaraan manajemen pelayanan sosial di Panti baik perencanaan, pengorganisasian, pelaksanaan dan pengawasan di panti asuhan hasana Pekanbaru.

Dengan kata lain penelitian kualitatif yang dapat memberikan jawaban pertanyaan tersebut secara lengkap. Menurut Robert K. Yin (2011:101) bukti atau data untuk keperluan studi kasus di dasarkan atas enam sumber bukti yaitu (1) dokumen, (2) rekapan arsip, (3) wawancara, (4) pengamatan langsung, (5) observasi partisipan, dan (6) perangkat - perangkat fisik. Selain sumber - sumber individual di atas ada beberapa prinsip yang perlu diperhatikan dalam pengumpulan data studi kasus, antara lain : (1) berbagai sumber bukti yaitu bukti dari dua atau lebih sumber, tetapi menyatu dengan serangkaian fakta atau temuan yang sama, (2) data dasar, yaitu kumpulan formal bukti yang berlainan dari laporan akhir studi kasus yang bersangkutan, dan (3) serangkaian bukti yaitu keterkaitan yang eksplisit antara pertanyaan pertanyaan yang diajukan, data yang terkumpul, dan konklusi - konklusi yang ditarik.

\section{HASIL}

Pemaparan penelitian ini menyajikan gambaran umum tentang kualitas manajemen pelayanan sosial di Panti di panti Hasanah Pekanbaru. Penelitian ini 
memberikan gambaran kualitas manajemen pelayanan sosial di lembaga pendidikan pentingannya manajemen pelayanan sosial bagi kemajuan pendidikan khususnya pada Panti Hasanah sebagai lembaga atau yayasan yang telah dikelola dengan baik, gambaran umum penelitian ini adalah mengungkap atau study kasus tentang keberadaan dan proses menejemen pelayanan sosial yang diselenggarakan oleh suatu lembaga pendidikan seperti panti asuhan hasana. Dalam penelitian ini akan menyajikan proses secara kualitatif sehingga gambaran hasil secara jelas terlihat dan secara khusus membahas apa yang terjadi dilapangan.

$$
\text { Berdasarkan hasil observasi, }
$$
wawancara dan dokumentasi yang diperoleh dilapangan maka dapat peneliti sajikan dalam hasil penelitian sebagai berikut. Secara operasional, proses manajemen yang diselenggarakan oleh lembaga Panti Hasanah Pekanbaru telah berjalan baik dan kualitas manajemen pelayanan sosial sudah berjalan sesuai dengan standar pelayanan sosial yang ada baik yang ditentukan yayasan maupun pemerintah melalui penilaian dalam akreditasirkan metode dan hasil yang dicapai dalam rangka meningkatkan mutu layanan sosial.

Pertama, berdasarkan penjelasan hasil wawancara dan observasi yang dilakukan, maka dapat disimpulkan bahwa perencanaan yang dilakukan sebelum pelaksanaan kegiatan pelayanan sosial, sedangkan seluruh civitas yang ada di yayasan maupun Panti Hasanah juga terlibat didalamnya dengan mengetengahkan kebersamaan dan toleransi sehingga berjalan dengan baik dan lancar.

Kedua, Hal lain juga ditemukan dalam proses pengorganisasian pelayanan sosial di Panti Hasanah dan dapat pula disimpulkan bahwa pengorganisasian pelayanan sosial di Panti Hasanah baik, bersifat koordinatif kerjasama dan saling mendukung, kerjasama dan koordinasi baik bersifat internal maupun eksternal, aktivitas bersama yang diperkuat dengan beberapa kerjasama yang dijalin dalam bentuk MOu. Hal ini dapat dilihat pada dokumentasi yang ada.

Ketiga, Setiap rencana didalam pelaksanaannya tidak serta merta berjalan dengan baik dan lancar terkadang muncul berbagai persoalan seperti; kegiatan terkendala masalah teknis di kelas, guru yang sakit dan tidak masuk kelas, ada kegiatan isidental baik didinas maupun kegiatan organisasi lainnya, kesemuanya memerlukan kebijakan secara langsung atau mengarahkan rencana yang sifatnya situasional. Pelaksanaan berubah sesuai situasi, selama tidak bertentangan dengan kaidah yayasan.

Keempat, Berdasarkan hasil wawancara peneliti dengan Kepala Panti Hasanahmenyatakan bahwa beliau sudah berusaha melakukan pengelolaan pelayanan sosial baik dari pegawai, pengasuh dan anak didik pada panti asuhan hasana.

\section{PEMBAHASAN}

Perencanaan, pengorganisasian , pelaksanaan dan Pengawasan dalam pelayanan sosial di Panti Asuhan Hasana Pekanbaru bertujuan untuk menjamin kinerja yang dicapai sesuai dengan rencana atau tujuan yang telah ditetapkan. Pada bagian ini aspek yang yang perlu diperhatikan oleh kepala sekolah adalah: (a) bagaimana evaluasi dilakukan dikaitkan dengan tujuan, dan (b) pemanfaatan hasil evaluasi.

Proses manajemen pelayanan sosial yang dilakukan sampai pada Pengawasan dilakukan secara berjenjang seperti anak diawasi oleh pengasuh, sedangkan kepala sekolah diawasi oleh pengawas sekolah maupun yayasan sekolah. Maka bentuk pengawasan yang dimaksud disini adalah evaluasi terhadap kegiatan yang telah dilakukan, sehingga aktivitas yang berlangsung maupun yang telah berlangsung 
memiliki kualitas yang baik dalam memberikan pelayanan kepada stake holder.

Lebih jauh Kepala panti asuhan hasana menyatakan bahwa untuk standar pembelajaran yang ada pada panti asuhan hasana telah disesuaikan dengan standar tingkat pencapaian perkembangan anak, dan sesuai dengan kelompok umur peserta didik. Kepala panti menyatakan bahwa selaku kepala sekolah selalu mengadakan pengawasan terhadap segala proses kegiatan yang ada disekolah sebagai rasa tanggung jawab saya, seperti halnya pengawasan yang saya lakukan terhadap proses pembelajaran, keadministrasian dan keberlangsungan sekolah. Tingkat pencapaian perkembangan menggambarkan pertumbuhan dan perkembangan yang diharapkan dicapai anak pada rentang usia tertentu. Hasil wawancara dengan Kepala Panti Hasanah dan Salmah, juga menyatakan tidak mengalami kendala yang cukup berarti dalam melaksanakan pembelajaran untuk mencapaian standar tingkat pencapaian perkembangan anak yang ada dipanti, dan sesuai dengan kelompok umur peserta didik.

Hasil wawancara dengan yayasan, dapat disimpulkan sebagai berikut; kegiatan manajemen pelayanan sosial pengawasan yang dilakukan terhadap guru dalam bentuk evaluasi terutama evaluasi belajar mengajar di kelas, yang kami lihat adalah laporan dari kepala dan pengasuh panti, sebagai yayasan evaluasi memiliki gambaran tentang bagaimana roda lembaga berjalan, maka intervensi yayasan terhadap pengawasan ini melalui evaluasi baik semesteran maupun tahunan.

Pelaksnaan pengawasan berlangsung sistematis dan hirarkis, dimana yayasan mengawasi kepala panti dan kepala sekolah secara keadministrasian melihat pembukuan yang ada serta proses layanan yang selama ini diberikan, untuk disahkan dan ditanda tangani, apabila terjadi kesalahan administrasi untuk segera diganti dan diperbaiki, sedangkan pengawasan juga dilakukan oleh ibu pengawas Kesimpulan secara umum Kepala Panti Hasanah yaitu menyatakan bahwa bentuk layanan sosial pada peserta didik (penerima manfaat di panti) yang di selenggarakan pada Panti Hasanah dan adalah Layanan pendidikan (baik ditingkat TK, SD, SMP bahkan di tingkat SMA/SMK) Layanan pendidikan yang diberikan secara Terpadu dan tidak terlampau banyak mengalami kendala, hanya kendala-kendala kecil yang tentunya bisa diatasi secara bersama-sama. Dalam hal ini, guru juga harus dapat mengambil keputusan atas dasar penilaian yang tepat ketika anak didik belum dapat membentuk kompetensi dasar, apakah kegiatan pembelajran di hentikan, diubah metodenya, atau mengulang dulu pembelajaran yang lalu. Guru harus menguasai prinsip - prinsip pembelajaran, pemilihan dan penggunaan media pembelajaran, pemilihan dan penggunaan metode, keterampilan, menilai hasil belajar, serta memilih dan menggunakan strategi atau pendekatan pembelajaran.

Secara umum dari hasil wawancara dengan Panti Hasanahdan diketahui bahwa guru-guru dan petugas selalu berupaya meninggkatkan kualitas dalam memberikan layanan kepada anak didik. Dan mereka mengaku juga berperan dalam kelompok yang lain, sehingga pengalaman mereka dalam melayani peserta didik membuat mereka selalu meninggkatkan kualitas.

Dari 5 orang pengasuh Panti Hasanah menyatakana bahwa setiap guru mendapatkan peran dan tanggung jawab untuk mengelola masing masing kelompok layanan yang diselenggarakan secara Terpadu. Selain itu 3 guru tersebut, juga bertugas mengelola pelyanaan pendidikan, meskipun mendapatkan tanggung jawab masingmasing, secara keseluruhan petugas bertanggung jawab juga kepada semua bentuk 
layanan yang ada. Begitu juga untuk pengasuh, pihak sekolah yang lain. Petugas Panti Hasanah berpendapat sama bahwa pengelompokan layanan yang diberikan pada peserta didik sudah tepat dan sudah memenuhi standar pengelompokan layanan panti asuhan hasana yang ditetapkan Kementerian Pendidikan Nasional, yang dituangkan dalam Permendiknas No. 58 Tahun 2009.

Petugas Panti Hasanah juga berpendapat sama, bahwa tidak mendapatkan kendala yang terlampau berarti dalam melaksanakan layanan sosial kepada peserta didik. Petugas mengaku sangat dekat dengan anak-anak peserta didik, bahkan untuk pengajian guru-guru memsebelum kegiatan inti mereka sekolah, perlakukan peserta didik seperti anak sendiri. Panti Hasanahdan mempunyai banyak kemampuan dalam mendidik anak-anak mereka. Karena hasil pengamatan umum, dari masyarakat bahwa seiring berjalannya waktu, jumlah peserta didik pada Panti Hasanah dan semakin banyak.

Hal itu antara lain disebabkan manajemen pelayanan sosial yang diberikan kepada peserta didik mengacu pada standar Anak di Panti. Petugas Panti Hasanah, menyatakan bahwa mereka merasa pengelompokan anak-anak mereka sudah sesuai dengan perkembangan umur anakanak, dan juga sesuai dengan keinginan mereka sebagi orang tua. Keluarga peserta didik juga mengaku, bahwa pada awal tahun pelajaran saat pendaftaran anak mereka ke panti asuhan hasana, mereka sudah diberitahu kelompok-kelompok Iayanan yang diberikan panti asuhan hasana Terpadu, dan itu disesuaikan dengan umur masing-masing anak. Pihak panti asuhan hasana juga sudah memberitahu bahwa layanan kelompokkelompok yang ada pada panti asuhan hasana disesuaikan dengan petunjuk tentang penyelenggaraan panti asuhan hasana atau sesuai dengan aturan yang ada. orang tua peserta didik, juga menyatakan tidak mengalami kendala dengan pengelompokan peserta didik seperti yang ada di panti asuhan hasana terpadu. Sebagai contoh, peserta didik dikelompokkan pada kelompok yang sesuai dengan umur mereka, kemudian layanan yang diberikan disesuaikan dengan ruang lingkup perkembangan peserta didik seperti nilai-nilai Agama dan Moral, Sosial Emosional, Bahasa Kepala Panti Hasanah menyatakan bahwa pembelajaran kepada peserta didik dipanti asuhan hasana dimaksudkan untuk pencapaian perkembangan peserta didik yangdisesuaikan dengan tingkat usianya. Dan juga disesuaikan dengan kelompok layanan yang diberikan atau diikuti peserta didik.

TABEL 2

REKAPITULASI TEMUAN PENELITIAN

\begin{tabular}{|c|c|c|c|}
\hline NO & $\begin{array}{c}\text { Fokus } \\
\text { peneliti } \\
\text { an }\end{array}$ & $\begin{array}{l}\text { Sub Fokus } \\
\text { penelitian }\end{array}$ & $\begin{array}{c}\text { Temuan } \\
\text { Penelitian }\end{array}$ \\
\hline 1 & $\begin{array}{c}\text { Kualitas } \\
\text { Manaje } \\
\text { men } \\
\text { pelayan } \\
\text { an } \\
\text { sosialdi } \\
\text { Panti } \\
\text { dHasana } \\
\text { hKota } \\
\text { pekanba } \\
\text { ru }\end{array}$ & $\begin{array}{l}\text { 1. Perencan } \\
\text { aan } \\
\text { pelayanan } \\
\text { a sosial }\end{array}$ & $\begin{array}{l}\text { Kegiatan } \\
\text { perencanaan yang } \\
\text { berlangsung pada } \\
\text { Panti } \\
\text { Hasanahberlangsu } \\
\text { ng baik dan } \\
\text { semua terlaksana } \\
\text { berdasarkan } \\
\text { kondisi yang } \\
\text { terjadir Secara } \\
\text { manajemen segala } \\
\text { sesuatur yang } \\
\text { berkaitan dengan } \\
\text { manajemen telah } \\
\text { diarsipkan } \\
\text { sedemian rupa } \\
\text { baik tertulis } \\
\text { maupun secara } \\
\text { lisan. Akan tetapi } \\
\text { hanya dilakukan }\end{array}$ \\
\hline
\end{tabular}




\begin{tabular}{|c|c|c|c|}
\hline NO & $\begin{array}{l}\text { Fokus } \\
\text { peneliti } \\
\text { an }\end{array}$ & $\begin{array}{l}\text { Sub Fokus } \\
\text { penelitian }\end{array}$ & $\begin{array}{c}\text { Temuan } \\
\text { Penelitian }\end{array}$ \\
\hline & & & $\begin{array}{l}\text { secara internal } \\
\text { oleh personil } \\
\text { sekolah } \\
\text { sedangkan orang } \\
\text { tua } \\
\text { disosialisasikan } \\
\text { saja setelah } \\
\text { perencanaan } \\
\text { dirumuskan }\end{array}$ \\
\hline & & 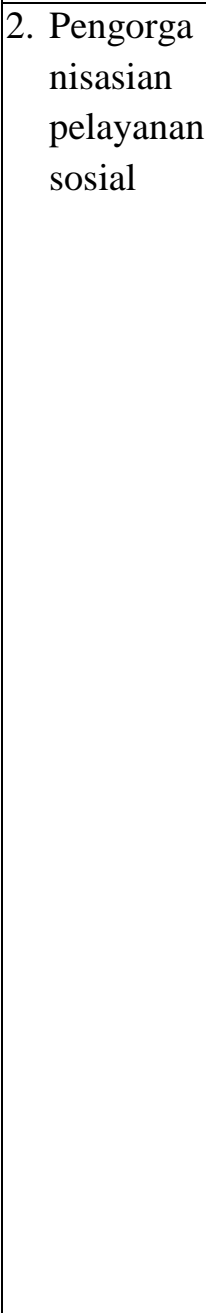 & 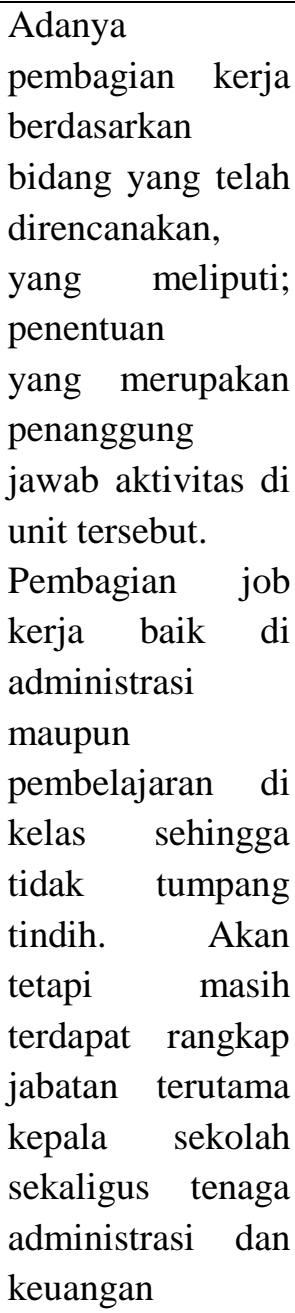 \\
\hline & & $\begin{array}{l}\text { 3. Pelaksana } \\
\text { an } \\
\text { pelayanan } \\
\text { sosial }\end{array}$ & $\begin{array}{l}\text { Kepala panti } \\
\text { menjalankan } \\
\text { tugas } \\
\text { kepemimpinannya }\end{array}$ \\
\hline
\end{tabular}

\begin{tabular}{|c|c|c|c|}
\hline NO & $\begin{array}{c}\text { Fokus } \\
\text { peneliti } \\
\text { an }\end{array}$ & $\begin{array}{l}\text { Sub Fokus } \\
\text { penelitian }\end{array}$ & $\begin{array}{l}\text { Temuan } \\
\text { Penelitian }\end{array}$ \\
\hline & & & $\begin{array}{l}\text { mengarahkan, } \\
\text { membina, } \\
\text { mengkoordinir } \\
\text { dan memotivasi } \\
\text { para petugas } \\
\text { Kegiatan guru dan } \\
\text { petugas dalam } \\
\text { pembelajaran } \\
\text { mulai dari } \\
\text { pelyanan } \\
\text { registrasi awal } \\
\text { sampai } \\
\text { Melaksanakan } \\
\text { kegiatan secara } \\
\text { optimal sesuai } \\
\text { dengan peran, } \\
\text { tugas dan } \\
\text { tanggung } \\
\text { jawabnya }\end{array}$ \\
\hline & & $\begin{array}{l}\text { 4. } \text { Pengawas } \\
\text { an } \\
\text { pelayanan } \\
\text { sosial }\end{array}$ & $\begin{array}{lr}\text { pengawasan } \\
\text { dilakukan } & \text { oleh } \\
\text { yayasan } & \text { seperti } \\
\text { aktivitas } & \text { seluruh } \\
\text { kegiatan } & \text { baik } \\
\text { keadministrasian } \\
\text { sampai } & \text { proses } \\
\text { pembelajaran } \\
\text { secara rala berkala } \\
\text { dalam } 3 & \text { bulan } \\
\text { sekali } & \text { dan } \\
\text { isidental } & \text { dalam } \\
\text { tiap } & \text { bulannya, } \\
\text { sedangkan } & \\
\text { laporan } & \text { kepala } \\
\text { kepada } & \text { yayasan } \\
\text { dalam } & \text { bentuk } \\
\text { rapat } & \text { setiap } \\
\text { minggu } & \text { dihari } \\
\text { sabtu. } & \end{array}$ \\
\hline
\end{tabular}


Berdasarkan hasil penelitian yang telah diungkapkan diatas, bahwa dalam penelitian ini lebih terfokus pada proses kualitas manajemen pelayanan sosial yang di lakukan Panti Hasanah pekanbaru yang meliputi proses perencanaan, pengorganisasian, pelaksanaan dan proses evaluasi. Seperti halnya kondisi manajemen pelayanana sosial yang ada di Panti Hasanah telah sesuai dengan proses yang terjadi seperti dalam hal.

Pertama, Panti Hasanah sangat memahami bahwa untuk memberikan arahan terhadap kerja apa yang harus dilakukan dimasa mendatang perlu perencanaan diberbagai aspek dan tingkat manajerial. Dengan rencana, karyawan, guru dan civitas akademika Panti Hasanah dapat mengetahui apa yang harus mereka capai, dengan siapa mereka harus bekerja sama, dan apa yang harus dilakukan untuk mencapai tujuan organisasi, selanjutnya membuat strategi untuk mencapai tujuan itu, dan mengembangkan rencana aktivitas kerja organisasi.Perencanaan merupakan proses terpenting dari semua fungsi manajemen karena tanpa perencanaan fungsi-fungsi lain pengorganisasian, pengarahan, dan pengontrolan tak akan dapat berjalan. Kegiatan perencanaan yang berlangsung pada Panti Hasanah berlangsung baik dan semua terlaksana berdasarkan kondisi yang terjadi. Secara manajemen segala sesuatu yang berkaitan dengan manajemen telah diarsipkan sedemian rupa baik tertulis maupun tidak.

Kedua, Pada penelitian yang dilakukan di Panti Hasanah pekanbaru untuk indikator kualitas pengorganisasian yang berlangsung di lembaga tersebut telah berjalan sesuai dengan apa yang diharapkan karena setiap unit yang ada berjalan dan melakukan koordinasi yang baik. Kegiatan lain yang mampu diorganisir dengan baik adalah administrasi baik pendaftaran sampai pada pelayanan terhadap anak didik sesuai dengan prosedur dan ketentuan yang ditetapkan, karena pengorganisasian adalah merupakan fungsi kedua dalam manajemen dan pengorganisasian didefinisikan sebagai proses kegiatan penyusunan struktur organisasi sesuai dengan tujuan-tujuan, sumber-sumber, dan lingkungannya. Pengorganisasian di panti Asuhan Hasana Panti Hasanahtidak hanya sebatas aktifitas fisik, akan tetapi koordinasi keadministrasian juga dilakukan dengan berbagai aktivitas seperti kepala sekolah melakukan cros check dalam perencanaan tahunan, semesteran, mingguan maupun harian, karena setiap administrasi yang dilakukan selalu berkaitan dan disingkronkan antar program.Selama ini kerjasama dan koordinasi yang terjadi tidak hanya sekolah yang melakukan akan tetapi yayasan juga ikut serta didalamnya, akan tetapi tidak terlalu jauh intervensi terhadap aktivitas, sebatas hirarki kegiatan.

Ketiga, hasil penelitian menunjukkan bahwa pembentukan tim pelayanan dikembangkan dengan membentuk yang sudah ada. semakin kuat karena mampu menyatukan dan menyelaraskan berbagai kelembagaan dimasyarakat. Hal ini juga melibatkan dewan pakai, ahli bidang Anak di Panti dan sebagainya, senada dengan Hendarman, penelitian tentang peran dewan pendidikan dalam meningkatkan mutu pelayanan sosial, hasil penelitian menunjukkan bahwa dewan pendidikan telah berperan aktif dalam memberikan kontribusi dalam upaya peningkatan mutu pelayanan sosial dengan mengacu pada standar pendidikan nasional. Sehingga pelaksanaan atau actuating dalam manajemen tercapai sesuai tujuan.

\section{KESIMPULAN}

Berdasarkan hasil penelitian dan pembahasan yang telah dingkapkan di atas, maka sesuai dengan tujuan penelitian dapat ditarik kesimpulan bahwa perencanaan 
pelayanan sosial panti asuhan hasana dilakukan sebelum pelaksanaan kegiatan, sedangkan seluruh civitas yang ada di yayasan maupun panti asuhan hasana it panti hasanah juga terlibat di dalamnya dengan mengetengahkan kebersamaan dan toleransi sehingga berjalan dengan baik dan lancar. Keterlibatan seluruh unsur dalam perencanaan menjadi hal yang sangat penting baik yang dibuat diawal tahun ajaran baru, pertengahan semester, mingguan bahkan harian. Kepala sekolah, yayasan dan guru melaporkan rencana kerja secara hirarki atau bertingkat seperti, guru memberikan rencana kegiatan kepada kepala sekolah, kepala sekolah kepada yayasan, dan yayasan memberikan timbal balik atau respon dari laporan tersebut.

Pengorganisasian pelayanan sosial di Panti Hasanah yang dilakukan antar unit yang ada atau antar lintas kelas sesuai dengan prosedur sebelum pelaksanaan kegiatan atau kegiatan yang sedang berlangsung, seperti : adanya koordinasi kegiatan, kerjasama antar guru, kepala sekolah dan yayasan dalam pengembangan lembaga. Koordinasi juga terjadi baik secara internal maupun eksternal. Secara internal dilakukan dalam lembaga dan unit yang ada, guru dengan guru, guru dengan kepala sekolah. Sedangkan eksternal antara lembaga Panti Hasanah dengan organisasi lembaga lain.

Pelaksanaan pelayanan sosial di Panti Hasanah yang dilakukan dalam berbagai aktivitas rutin di lembaga baik di kelas proses pembelajaran, di luar lembaga pada event tertentu, penggunaan metode sampai keadministrasian berjalan dengan baik, walau menurut beberapa sumber yang dimintai keterangan masih terdapat permasalahan kesalah pahaman seperti dalam pelaksanaan kegiatan, akan tetapi masih dapat diatasi dengan memberikan kesempatan berkreativitas sepanjang tidak keluar dari visi dan misi yayasan.
Pengawasan pelayanan sosial di Panti Hasanah dalam hal evaluasi berbagai kegiatan sesuai dengan pelaksanaan yang dilakukan dan rencana yang telah dilakukan seperti persiapan dan pelaksanaan proses pembelajaran di kelas maupun antar lembaga melibatkan seluruh civitas akademika yayasan

\section{DAFTAR KEPUSTAKAAN}

Aedi Nur, 2014, Pengawasan Pendidikan; Tinjauan teori dan Praktek, Jakarta, Rajagrafindo.

Ade Cahyana, 2010, Upaya Peningkatan Mutu Sekolah Melalui Otonomi Satuan Pendidikan, Jurnal Pendidikan dan Kebudayaan, Vol.16 No.2 Hal.109

Ahmad Zumaro, 2011, Manajemen Pendidikan Islan, konsep ketertiban, kerapian dan keharmonisan di dalam Al Qur'an, Jurnal Tarbawiyah. Vol.8 no. 1 hal 43

Aminuddin, 2004,Pengantar Apresiasi Karya Sastra, Bandung: Sinar Baru Algensindo.

Asmani jamal, 2009, Manajemen Strategi Anak di Panti, Yogyakarta, Diva press.

Abu Sofyan, 2008, Manajemen Program Anak di Panti (study Deskriptif kualitatif di Dinas pendidikan Kabupaten Musi rawas).

Bambang Indriyanto, 2013, menguak tabir kotak Pandora manajemen pendidikan, Jurnal Pendidikan dan kebudayaan, Vol.19 No.2 Hal,279

Berkell, Diane E. 1992, Identification, Education, and Treatment, New Jersey : Lawrence Erlbaum Associates, Inc, Bogdan, Robert C. 1992, Qualtative Research for Education, An Introduction to Theory and Methods, Boston : Allyn and Bacon, 
Borg, Walter et all 1989. Educational Research. New York : Longman,

Bryson, Jhon M,1991, Strategic planning For public and Non Profit Organization. San Pransisco; Jossey-Bas publisher.

Dinas Pendidikan Kota Pekanbaru, arsip kasie PNF-PNFI, tahun 2014

Dirjen PANTI ASUHAN HASANA, 2013, Petunjuk Teknis Penyelenggaraan Kelompok Bermain, Jakarta.

Dirjen PANTI ASUHAN HASANA, 2013, Petunjuk Teknis Penyelenggaraan Taman Kanak-kanak, Jakarta

Dirjen PANTI ASUHAN HASANA, 2013, Petunjuk Teknis Penyelenggaraan Taman Penitipan Anak, Jakarta

DirjenPANTI ASUHAN HASANA, 2010, PeraturanMendiknastentangstandar PANTI ASUHAN HASANA, Dirjen, Jakarta.

Eurypedia, Management Staff for Early Childhood andSchool Education,

Gary, Yulk, 2002, Leadreship in Organizations New York : Prentice Hall.

Goerge R.Terry, Alih bahasa GA Ticoalu, 2010, dasar-Odasar Manajemen, Bumi Aksara, Jakarta

G.Nurrochim,(2006)

peningkatanMutuSekolah, JurnalDidaktika, Vo. 7 N0.1. hal 21-35

Goerge R.Terry, Alih bahasa J. Smith, 2003, Prinsip-prinsip Manajemen, Bumi Aksara, Jakarta

Harjanto, 2011, perencanaan Pengajaran, Rineka Cipta, Jakarta

Hairiyah, 2008, Pengelolaan dan pengembangan Lembaga pendidikan islam, jurnal Cendekia, Vol 6 No.2 hal 269-283

Hendarman, 2012, peran dewan pendidikan dalam meningkatkan mutu pelayanan pendidikan, Jurnal Pendidikan dan Kebudayaan, Vol.18 No.1 hal 34-44.
Herbert Simon, 2010, Administrative behavior, BumiAksara, Jakarta

Haryetti, 2011. Pengaruh pengawasan dan disiplin kerja Terhadap kinerja Karyawan PT Swakarya Indah Busana Tanjung pinang kepulauan Riau, Jurnal El Riyasah, Vol 2 No. 2 Hal 193

HR Tilaar, 2009, Kredo Pendidikan, Jakarta : Rama Percetakan.

Irine Diana, 2008, Manajemen, Mitracendekia, Yogyakarta

Jhon W creswell , 2011, AlihBahasaM.Diah, PenelitianKualitatif, Umri Press Pekanbaru

JuliaBrannen2005,MemaduMetodePenelitian KualitatifdanKuantitatif, Samarinda, Pustakapelajar

John M Bryson, 2004, Strategic Planning For Public and Non Profit organization.Josseybass, USA

Muhajir, Noeng, 2000, Metodologi Penelitian Kualitatif, Yogyakarta : Rake Sarasin

Nurhattati Fuad, 2006, manajemen Madrasah Aliyah Swasta di Indonesia, Jurnal Edukasi, Vol. 4 No. 3 hal 68.

Nurrahmi, 2014, Pengantar Manajemen, Benteng media, Pekanbaru

Nurrochim, 2006, Peningkatan Mutu Sekoilah, Jurnal Didaktika Islamika, Vol.7. No. 1 Hal. 21

Oslond, Joice S, et all, 2000, The Orgizational Behavior Reader, New Jersey : Prentice Hall.

Slavin, Robert R. 2006, Educational Psychology, (Boston : Pearson Educational, Inc.

Sondang P siagian, 2003, manajemenSumberdayamanusia, BumiAksara, Jakarta.

Spradley, James P,1980, Participant Observation, New york : Holt, Rinehart and Windston.

Suyanto Slamet, 2005, Dasar-Dasar Anak di Panti, Yogyakarta, Hikayat Publising, 
Sujiono, 2012, Konsep dasar Anak di Panti, Jakarta, PT Indeks,

Winardi, 2012, Asas-asas manajemen, Alumni, Bandung

Yamin, 2010, Panduan Anak di Panti, Jakarta, Gaung Persada 